\title{
Crime and Unemployment in South Africa; Revisiting an Established Causality: Evidence from the Kwazulu Natal Province
}

\author{
N.G. Tshabalala, PhD \\ Department of Sociology, University of Zululand, \\ P/bag X1001, KwaDlangezwa, 3886, South Africa \\ Email: Jeffrey058@gmail.com
}

\section{Doi:10.5901/mjss.2014.v5n15p519}

\begin{abstract}
The study investigated the effects of unemployment on the rate of crime in South Africa with reference to Richards Bay and Empangeni communities in Kwa-Zulu Natal Province. Unemployment is considered to be the root cause of many problems South Africa is facing today such as crime, poverty and suicide. Crime in particular, acts as a symptom of deeper socio-political issues in South Africa. Using a survey design, data was collected from a sample of 110 respondents. The respondents consisted of 60 unemployed participants, 20 experts on crime control and labour issues as well as 30 convicts. The results of the study showed that the low level of education is responsible for the high rate of unemployment and bears a direct relationship with the high rate of crime. In the light of the findings of the study, it was recommended that there is a need for educational programmes aimed at reducing vulnerability to crime and the need for special job creation projects and skills training programmes.
\end{abstract}

Keywords: Crime, education, unemployment, poverty

\section{Introduction}

In spite of limited empirical evidence, the idea that poverty creates crime has been a long-held hypothesis. However, in the developed world, there have been attempts to obtain this evidence. For example, Raphael and Winter-Ebmer (2001) reported that decreases in property crime rates in the USA can be explained, in part, to decreases in unemployment rates. Similarly, Ludwig et al. (2001) concluded that giving families the opportunity to move to neighborhoods with lower levels of poverty reduces criminal behaviour among teenagers. There have also been empirical links between poverty and violent crime (see Kelly, 2000). In the developing world, studies (Fajnzylber et al., 2000; Dreze and Reetika, 2000) provided empirical supported for the crime - poverty hypothesis. However, the direction of causality in these studies has been contentious. Thus it has be argued in reverse that increasing rates of crimes leads to increases in poverty (Fafchamps and Minten, 2006)

In 1997 Statistics South Africa reported that South Africa had an unemployment rate of 38\%. The upper estimate of $38 \%$ is considerably high by international standards. Kingdon and Knight (2001) argued that there is evidence of very long mean unemployment duration for a high proportion of the jobless in South Africa, portending the depth as well as breadth of the unemployment crisis. 37\% of the narrowly defined unemployed had been out of work for more than 3 years and another 30\% had been unemployed for between 1 and 3 years (Stats SA, 1998). The Erstwhile Central Statistical Office stated that the labour force participation rate has been declining steadily every year from 1970 to 1995. It has been argued that the low probability of finding work is an important reason for lack of search for jobs. Stats SA's 1997 Special Retrospective Survey of Employment and Unemployment showed that the main reasons given by the unemployed for having stopped searching are a loss of hope of finding work (33\%), a lack of jobs in the areas in which they live (25\%), and a lack of money for transport to look for work (18\%). Stats SA report connotes that often unemployed persons people know that there are very few, if any, jobs available, they may feel that the financial and other costs of work-seeking are not worthwhile.

Too many South Africans are unemployed (Banerrjee et al., 2006). At the time of transition to democracy in 1994, unemployment was substantially lower than its current levels. By the end of the 1990 , unemployment had jumped to 30 percent before declining slightly. The rate of unemployment has increased substantially since the African National Congress came to power after South Africa's first democratic elections in 1994 (Banerjee et al., 2006). Unemployment doubled between 1995 and 2001, going from 15.6 percent to 30.3 percent. While the figure has decline sometimes, it still is substantially higher than in 1995. Seekings and Nattrass (2006) concluded that instead the unemployment level has 
increased since the mid-1970s, it does appear overall however, that unemployment grew during the mid-1970s, and continued to grow throughout the 1980's. Unemployment is considered to be the root cause of many other problems South Africa is facing today. Crime in particular acts as a symptom of deeper socio- political issues in South Africa. South Africa has seen a drastic increase in the level of awareness of crime since the 1960s, there has been growing international awareness of the state's lack of success in its attempt to eliminate crime. It has been argued that having a job with a good salary is likely to reduce the chances that an individual will turn to criminal activities (Hirsch, 1969).

\section{The Present Study}

The present study sought therefore to explore the association between unemployment and crime and other social variables, which lead to frustration in the individual who make up society.

Aims of the Study

1. To examine the relationship between unemployment and the rate of crime in South Africa.

2. To establish the relationship between the individual's level of education and the rate of crime and unemployment.

3. To determine the relationship between the level of cooperation and integration between the ministry of labour and the department of correctional services in reducing the level of crime and unemployment in South Africa.

4. To determine the relationship between government legislation on minimum wage and its effect on the unemployment and crime in South Africa.

\section{Research Methods}

The study covers a population of 110 respondents which consisted of 60 unemployed participants, 20 experts on crime control and labour issues, as well as 30 convicts which we selected with the assistance of the National Institute of Crime Prevention and Reintegration of Offenders situated in Empangeni. We used questionnaires to solicit the necessary information on the impact of unemployment on the rate of crime. Data was analyzed using frequencies and percentages. Further, hypotheses were tested using the chi-square $(X)$ nonparametric tests which is applicable to a wide range of research problems. The chi-square allows us to test the significance of the difference between a set of observed (fo) and expected (fe), that is, between the given facts and the theoretical anticipation, in order to assess whether the facts support the theoretical considerations.

\section{Results}

In order to establish the effects of unemployment on the rate of crime in South Africa, simple percentages, oral interviews, personal observation, chi square analysis, correlation analysis as well as themes that emerged from the interviews were used to investigate the identified research hypotheses and problems associated with unemployment.

The hypotheses of the study:

- There is a relationship between unemployment and rate of crimes in South Africa.

- There is a relationship between the individual's level of education and the rate of crime and unemployment.

- There is a relationship in the level of cooperation and integration between the ministry of labour and the department of correctional services in reducing the level of unemployment and crime in South Africa.

- There is a relationship between government's legislation on minimum wages and its effects on the rate of crime and unemployment in South Africa.

Table 1: Residential distribution of the Unemployed respondents in Urban and Rural Areas

\begin{tabular}{|l|c|c|c|c|c|c|}
\hline \multicolumn{1}{|c|}{ Towns } & Area & Rural & $\%$ & Urban & $\%$ & Total \\
\hline Empangeni & $\mathrm{I}$ & 3 & 32.0 & 11 & 32.0 & 14 \\
\hline Richards Bay & $\mathrm{li}$ & 3 & 23.0 & 11 & 23.0 & 14 \\
\hline Mthunzini & $\mathrm{lii}$ & 4 & 30.8 & 9 & 19.0 & 13 \\
\hline Esikhawini & $\mathrm{IV}$ & 2 & 15.4 & 8 & 19.0 & 10 \\
\hline Vulindlela & $\mathrm{V}$ & 1 & 7.7 & 7 & 15.0 & 8 \\
\hline \multicolumn{1}{|c|}{ Total } & \multicolumn{1}{|c|}{13} & 100 & 47 & 100 & 60 \\
\hline
\end{tabular}


Table 1 illustrates that 47 (78\%) of the unemployed respondents interviewed lived in urban areas. Only $13(22 \%)$ of the respondents lived in rural areas. This research confirms that our urban centres have more of the unemployed than the rural areas. This large number of the unemployed urbanites can be attributed to the regular movement of people from the rural areas to the urban centres with the hope of getting a job. Unfortunately, the dreams of those rural-urban migrants do not come true in terms of job opportunities and this makes them to turn to criminal activities in order to make a living.

\subsection{Correlational Analysis}

At this juncture we shall examine if there is any correlation between the residential and unemployment rates shown in table 1.

Table 2: Chi Square tests for residential location and unemployment

\begin{tabular}{|c|c|c|c|c|}
\hline $\mathbf{X}$ & $\mathbf{X 2}$ & $\mathbf{Y}$ & $\mathbf{Y 2}$ & $\mathbf{X Y}$ \\
\hline 11 & 121 & 3 & 9 & 33 \\
\hline 12 & 144 & 3 & 9 & 36 \\
\hline 9 & 81 & 4 & 16 & 36 \\
\hline 8 & 64 & 2 & 4 & 16 \\
\hline 7 & 49 & 1 & 1 & 7 \\
\hline$\sum \mathbf{X}=\mathbf{4 7}$ & $\sum \mathbf{x}=\mathbf{4 5 9}$ & $\sum \mathbf{y}=\mathbf{1 3}$ & $\sum \mathbf{y 2}=\mathbf{3 9}$ & $\sum \mathbf{x y}=\mathbf{1 2 8}$ \\
\hline
\end{tabular}

Table 2 confirms that there is a positive correlation between the residential areas (urban) and the rate of unemployment. Unemployment is more associated with the urban areas than rural areas. Perhaps this is why we have more crimes committed in urban areas than rural areas. The unemployed are likely to take to unapproved means (crime) in order to survive.

Generally speaking, migration from rural to urban centres by the unemployed is primarily an economic phenomenon which for individual migrant can be a quite rational decision despite the existence of urban unemployment. The economic model postulates that migration proceeds in response to urban - rural differences in expected rather than actual earnings. The fundamental premise is that migrants consider the various labour market opportunities available to them, as between urban and rural sectors, and choose the one which maximises their expected gains from migration. Expected gains are measured by: 1) the differences in real incomes between rural and urban working and 2), the probability of a new migrant obtaining an urban job. In terms of the economic theory on rural urban migration, Michael Todaro is of the view that members of the labour force, both actual and potential compare their expected incomes from a given horizon in the urban sector (i.e. the difference between returns and costs of migration) with prevailing average rural incomes and migrate if the former exceeds the latter. In the classical example of the above situation, Todaro (1977) argues that an average unskilled or semi-skilled rural worker has a choice between being a farm labourer (working his own land) for an annual average real income, say 50 units, or migrating to the city where a skilled worker with his skill or educational background can obtain a wage employment yielding an annual real income of 100 units. The more commonly used economic model of migration which places exclusive emphasis on the income difference factor as the determinant of the decision to migrate would indicate a clear choice in this situation. The worker would seek the higher paying urban job. It is important for us to recognise however that these migration models were developed largely in the context of advanced industrial economies and as such implicitly assumes the existence of full or near-full employment.

In a full employment environment, the decision to migrate can be predicated solely on securing the highest paid job wherever it becomes available. Simple economic theory would then rather indicate that such migration should lead to a reduction in wage differentials through the interaction of the forces of supply and demand, both in areas of emigration and points of immigration. Unfortunately such analyses as that given by Western Economists are not realistic in the context of South Africa and other Third World countries. In the first place, South Africa and other developing countries are beset by a chronic and serious unemployment problem, with the result that a typical migrant cannot expect to get highly paid urban job immediately. It is more likely therefore that on entering the urban labour market the migrant will either become totally unemployed or will seek casual and part-time employment in that urban sector. In view of this, it is suggested that in making a decision to migrate from the rural areas to the urban area, the migrant must balance the probabilities and risks of being unemployed or underemployed for a considerable period of time against the positive urban-rural real income differential. 
Our submission in this research is that even when we bridge the income difference between the urban and rural workers in South Africa those in the rural areas will still move to the urban centres for other social amenities and psychological gratification. The above problem notwithstanding, some possible measures will be suggested on how to minimise the rural-urban migration since the movement can never be stopped but it can only be minimised or checked.

\subsection{Educational Expansion}

The apartheid government in South Africa created a large mass of uneducated and unemployable individuals through the bantu education system among the blacks. This has contributed to the influx of the half- baked, uneducated individuals who migrate from rural areas to the urban centres in search of employment. Unfortunately, employers in the urban centres tend to use educational attainments and qualification as a means of recruitment. Those with a better qualification are offered better jobs and positions. In recent times, jobs which could formerly be filled by those with primary education (sweepers, messengers, filling clerks) now require secondary certificates (clerks, typists, book keepers) now necessitate a degree. It follows that for any given urban wage, if the probability of success in securing a modern sector job is higher for those with more education their expected income differential will also be higher and they will be more likely to migrate to the urban centres.

Table 3: The Marital Status of those who were convicted of crimes

\begin{tabular}{|l|c|c|c|}
\hline Marital status & Unemployed when crime was committed & Employed when crime was committed & Total \\
\hline Single & 2 & 1 & 3 \\
\hline Married & 16 & 2 & 18 \\
\hline Divorced & 4 & 2 & 6 \\
\hline Widowed & 2 & 1 & 3 \\
\hline \multicolumn{1}{|c|}{ Total } & $\mathbf{2 4}$ & $\mathbf{6} 2$ & $\mathbf{3 0}$ \\
\hline
\end{tabular}

Table 3 shows that the majority of those who committed crime when they were unemployed are married. The propensity for those who are unemployed and married to commit crime can be attributed to family responsibilities especially where there is no social security for the unemployed in our society, putting pressure and stress upon the head of the family to provide means of a livelihood for the family. Males as head of the family retain ultimate responsibilities for family finance. In South Africa and other African countries, a man as the head of the family is expected to take proper care in terms of finance and other subsistence expenses within the family. The inability of the head of the family to perform the above functions, the individual is not only seen as a failure in the community but as a non-existent entity with other stigma placed on the individual.

In order to avoid such stigma, the man would go to any length to provide the family with all necessary facilities to live a proper life. At this point, we will now use the correlational analysis to examine critically if there is any relationship between marital status and the propensity of the unemployed to commit crime as shown in table 3.

Table 4: Chi Square tests for Unemployment and Crime by Marital status

\begin{tabular}{|c|c|c|c|c|}
\hline$X$ & $\mathrm{X} 2$ & $\bar{Y}$ & Y2 & $\overline{X Y}$ \\
\hline 2 & 4 & 1 & 1 & 2 \\
\hline 16 & 32 & 2 & 4 & 32 \\
\hline 4 & 16 & 2 & 4 & 8 \\
\hline 2 & 4 & 1 & 1 & 2 \\
\hline$\sum X=24$ & $\sum \times 2=56$ & $\sum y=6$ & $\sum y 2=10$ & $\sum x y=44$ \\
\hline
\end{tabular}

$\mathrm{R}=1.9$

Table 4 indicates a high and positive correlation between unemployment and crime by marital status. The above correlation coefficient confirms that there is a positive relationship between marital status and crime rates among the unemployed. As we have discussed above, the responsibilities of men who are married and unemployed may force them to commit crime so as to be able to provide food, shelter and other necessities for their family members, especially in our society where there are no adequate social security measures to take care of the unemployed and his family. Our research also shows that the commonest crimes committed by the unemployed are theft and fraud. This further 
buttressed the fact that the main reason for the unemployed committing the crimes of theft and fraud revolve around the means to survive.

Table 5: Percentage distribution of employment status of the respondents

\begin{tabular}{|l|c|c|}
\hline \multicolumn{1}{|c|}{ Distribution of respondents } & Number of respondent & $\%$ \\
\hline Unemployed & 60 & 55 \\
\hline Convicts (prisoners) & 30 & 27 \\
\hline Experts on crime control and labour matters & 20 & 18 \\
\hline Total & 24 & 6 \\
\hline
\end{tabular}

Table 5 above shows that $60(55 \%)$ of the respondents in this research are unemployed. $30(27 \%)$ of the respondents are convicts (prisoners) and $20(18 \%)$ of the respondents are experts of crime control. These experts include criminologists and those officers in the correctional services who have been dealing with crime. The rationale for selecting the above respondents is to enable us to gain insight into the propensity of individuals to commit crime as a result of unemployment problems, especially among those uneducated. The convicts (prisoners) were also selected so as to find out if they were unemployed at the time they committed the crime, experts on crime control were also selected so as to find the views on the relationship between unemployment and crime.

Table 6: the level of education of the unemployed and convicts (prisoners)

\begin{tabular}{|l|c|c|c|c|}
\hline \multicolumn{1}{|c|}{ Level of education } & Unemployed & $\%$ & Convicts (prisoners) & $\%$ \\
\hline University degree & 3 & 5 & - & - \\
\hline Diploma & 4 & 7 & - & - \\
\hline Standard 10 & 5 & 8 & 5 & 17 \\
\hline Standard 9 & - & - & 1 & 3 \\
\hline Standard 8 & 8 & 13 & 6 & 20 \\
\hline Below standard 8 & 30 & 50 & 12 & 40 \\
\hline Never went to school & 10 & 17 & 6 & 20 \\
\hline Total & 60 & 100 & 30 & 100 \\
\hline
\end{tabular}

Table 6 illustrates that the unemployed in this research are not well educated. 30 (50\%) of the unemployed never completed standard 8. Perhaps we may attribute the inability to secure jobs to the low level of education. The low level of education contributes to their failure to secure employment. The education of the people is seen in this research as an area that the government needs to work at or take seriously, if the rate of unemployment is to be reduced in South Africa, thus minimising the rate of crime.

Education in South Africa has been expected to produce committed citizens and help individuals to make the most of their cognitive capacity. The socialization function of education is increasingly appreciated, because, deepening one's knowledge can be a worthwhile endeavour in the long run even if there is no immediate practical benefit. Table 6 above also confirms that $50 \%$ of the unemployed respondents never completed standard 8 . This group can be regarded as drop outs. One of the major problems in South Africa in as far as education is concerned is the very high percentage of students who drop out before completing a particular education cycle. For example, it has been estimated that in South Africa, about 45 out of 100 students who enter primary school drop out before completion. In other countries like African and Asia, the median dropout rate is about 20-25 of every 100 students.

This large number of drop outs in South Africa joins the ranks of the unemployed. In view of the above discussion, there is an urgent need for the government to encourage individuals to complete their studies in both primary schools and tertiary institutions if the rate of unemployment is to be reduced. Table 6 shows that the majority 12 (40\%) of the convicts (prisoners) have very poor education. They did not complete standard 8. Perhaps poor education must have hindered them from getting a job, and this is likely to contribute to their propensity to commit crime. To confirm this statement, we will now examine how many of the prisoners were employed at the time they committed the crime. This is illustrated in table 7 below. 
Table 7: Employment status of prisoners when they were convicted

\begin{tabular}{|c|c|c|}
\hline Status of respondent convicts (prisoners) when they committed the crime & No of responses & $\%$ \\
\hline Employed & 8 & - \\
\hline Not employed & 22 & 100 \\
\hline Total & 30 & 100 \\
\hline
\end{tabular}

Table 7 shows that the majority of the convicts were unemployed when they committed crime. In this simple analysis, it became clear that unemployment has a direct bearing on the propensity of individuals to commit crime. The 22 convicts (prisoners) who are unemployed also made it clear during the interviews that they would not have been involved in criminal activities if they were to receive any form of social security when they lost their jobs. The South African government has not extended social security benefits to the unemployed, especially in the informal sectors, and this has contributed greatly to the high rate of crime.

The limited nature of protection in in terms of South African social security benefits has adversely affected the unemployed who worked previously in the informal sectors of the economy. This category of workers has not only been marginalized but has been excluded from social security benefits. This, of course, stems from the fact that the social insurance system notably unemployment insurance and compensation for work injuries and diseases, do not provide coverage to those outside formal employment. Social assistance measures seldom operate to the direct advantage of the informally employed. Due to the targeted nature of both social services and programmes, many of the unemployed from the informal sectors are excluded. It is clear therefore that the present social security system in South Africa is for purposes of providing a true safety net for the rural and urban poor and the informally employed and structurally unemployed amongst them, hugely deficient, operating within a paradigm were a consistent model for the alleviation of the unemployed is yet to develop.

Legally speaking, the exclusion of workers in the informal sectors from the social security benefits raises serious questions of a constitutional nature. Section 27(1) of the South Africa constitution grants the right to access social security (inclusive of the right to access social assistance) to everyone. This right is underpinned by the fundamental right to quality, enshrined in section 9. Jurisprudential the right to equal treatment has already been spelt out in the Bill of Rights in the South African constitution. However, we do not intend to discuss further legal issues involved in the exclusion of workers from the informal sectors from enjoying social security benefits because it is not within the paradigm of this study.

Table 8: The relationship between unemployment and the rate of crime

\begin{tabular}{|l|c|c|}
\hline \multicolumn{1}{|c|}{ Respondents } & $\begin{array}{c}\text { Yes, unemployed } \\
\text { increases rate of crime }\end{array}$ & $\begin{array}{c}\text { No, unemployment does not } \\
\text { increase the rate of crime }\end{array}$ \\
\hline Unemployed & 55 & 5 \\
\hline Convicts (prisoners) & 27 & 3 \\
\hline Experts on crime and labour matters & 18 & 2 \\
\hline Total & 100 & 100 \\
\hline
\end{tabular}

Table 8 shows that 55 respondents out of 60 unemployed respondents agree that unemployment increase the rate of crime in our society. Only 5 out of the 60 unemployed respondents did not agree that unemployment increases the rate of crime. With regard to the convicts (prisoners) 27 out of 30 are of the opinion that unemployment increases crime. Only 3 of the prisoners did not agree that unemployment increased the rate of crime. Among the experts on crime control and labour matter, 18 out of 20 respondents agree that unemployment increases the rate of crime. Only 2 out of 20 respondents did not agree that unemployment increases crime.

Hypothesis: the relationship between unemployment and crime. The relationship will be tested with the help of Chi square (X2) analysis.

$\mathrm{H} 0$ : Unemployment rate does not increase the rate of crime

$\mathrm{H} 1$ : unemployment rate increases the rate of crime. 
Table 9: Chi Square test for Unemployment and Crime

\begin{tabular}{|c|c|c|c|c|}
\hline \multicolumn{1}{|c|}{ Responses } & Unemployed & $\begin{array}{c}\text { Convicts } \\
\text { (prisoners) }\end{array}$ & $\begin{array}{c}\text { Experts on crime control } \\
\text { and labour matters }\end{array}$ & Total \\
\hline Unemployment rate increases the rate of crime & $55(54.5)$ & $27(27.3)$ & $18(18.2)$ & 100 \\
\hline Unemployment rate does not increase the rate of crime & $5(5.5)$ & $3(2.7)$ & $2(1.8)$ & 10 \\
\hline Total & 60 & 30 & 20 & 110 \\
\hline
\end{tabular}

Observed X2 $=7.74$

$\mathrm{Df}=2$

Critical value at 0.05 level of significance $=5.99$

Since X2 $=7.74$ and the critical value at 0.05 level of significance is 5.99 which is less than the observed X2 we therefore reject the $\mathrm{Ho}$ (null hypothesis and accept $\mathrm{H} 1$ (alternative hypothesis). Our inference from this chi square analysis is that unemployment contributes greatly to the high rate of crime in South Africa. A further statistical computation of the relationship between unemployment and crime, using the contingency coefficient analysis reveals that there is a positive relationship between unemployment and crime rate. In our research data, the contingency coefficient ' $C$ ' is 0.2 and this confirms a positive relationship.

Table 10: The relationship between low level of education and employment

\begin{tabular}{|l|c|c|c|c|}
\hline \multicolumn{1}{|c|}{ Responses } & Unemployed & $\begin{array}{c}\text { Convicts } \\
\text { (prisoners) }\end{array}$ & $\begin{array}{c}\text { Experts on crime control } \\
\text { and labour matters }\end{array}$ & Total \\
\hline Low level of education contributes to unemployment and crime & 51 & 23 & 16 & 90 \\
\hline Low level of education does not contribute to unemployment and crime & 9 & 7 & 4 & 20 \\
\hline Total & 60 & 30 & 20 & 110 \\
\hline
\end{tabular}

Table 10 shows that the majority of our respondents are of the view that low level of education contributes to high rate of unemployment. To test this statistically in relation to crime, we shall use the chi square to find out the relationship between low level of education and the rate of unemployment and crime.

Ho: low level of education does not contribute to unemployment and crime.

$\mathrm{H} 1$ : low level of education contributes to unemployment and crime.

Table 11: Chi Square test for Education and Unemployment

\begin{tabular}{|c|c|c|c|c|}
\hline \multicolumn{1}{|c|}{ Response } & Unemployed & $\begin{array}{c}\text { Convicts } \\
\text { (prisoners) }\end{array}$ & $\begin{array}{c}\text { Experts on crime / } \\
\text { labour matters }\end{array}$ & Total \\
\hline Low level of education contributes to unemployment and crime & $51(49.0)$ & $23(24.5)$ & $16(16.4)$ & 90 \\
\hline Low level of education does not contribute to unemployment and crime & $9(10.9)$ & $7(5.5)$ & $4(3.6)$ & 20 \\
\hline Total & 60 & 30 & 20 & 110 \\
\hline
\end{tabular}

Observed X2 = 10.9

Critical value at 0.05 level of significance $=5$. Since $X 2$ is greater than the critical value at 0.05 level of significance we reject the $\mathrm{Ho}$ (null hypothesis) and accept the $\mathrm{H} 1$ (alternative hypothesis). Our inference from this analysis is that low level of education among the populace is responsible for the high rate of unemployment and bears a direct relationship with high rates of crime. It must be buttressed that the relationship between low level of education and the rate of unemployment has been earlier established by academics, for example, the research work of Perry (1974) shows that many African secondary and high school drop outs experience difficulty in finding employment above the level of unskilled and semi-skilled occupations.

According to Allen (1986) unemployment is caused by jobs that demand workers with skills or other attributes not usually possesses by young people, and that young people fail to adapt to this situation. White and McRare (1989) in their research findings pointed out that unemployment is highly influence by the lack of qualifications and good education. 
Table 12: Cooperation between ministry of labour and the department of correctional services in minimising unemployment and crime

\begin{tabular}{|c|c|c|c|c|}
\hline Responses & Unemployment & \begin{tabular}{|c|} 
Convicts \\
(prisoners)
\end{tabular} & $\begin{array}{c}\text { Experts on crime } \\
\text { and labour matters }\end{array}$ & Total \\
\hline Yes, the above cooperation will minimise unemployment and crime & 53 & 24 & 18 & 96 \\
\hline No, the above cooperation will not minimise unemployment and crime & 7 & 6 & 1 & 14 \\
\hline Total & 60 & 30 & 20 & 110 \\
\hline
\end{tabular}

Table 12 shows that majority of our respondents are of the view that cooperation between the ministry of labour and the department of correctional services will help minimise the rates of crime and unemployment. For us to be able to establish the fact that the cooperation between the ministry of labour and the department of correctional services will help minimise the rate of unemployment and crime we have to use the chi square $(\mathrm{X} 2)$ to fully establish the facts.

Ho: the cooperation between the ministry of labour and the department of correctional services will not help minimise unemployment.

$\mathrm{H} 1$ : the cooperation between the ministry of labour and the department of correctional services will help to minimise unemployment.

Table 13: Chi Square test for cooperation between labour and correctional services

\begin{tabular}{|c|c|c|c|c|}
\hline Responses & Unemployment & $\begin{array}{c}\text { Convicts } \\
\text { (prisoners) }\end{array}$ & $\begin{array}{c}\text { Experts on crime and } \\
\text { labour matters }\end{array}$ & Total \\
\hline Yes, the above cooperation will minimise unemployment and crime & $53(52.4)$ & $24(26.2)$ & $19(17.5)$ & 96 \\
\hline No, the above cooperation will not minimise unemployment and crime & $7(7.6)$ & $6(3.8)$ & $1(2.5)$ & 14 \\
\hline Total & 60 & 30 & 20 & 110 \\
\hline
\end{tabular}

Observed $\mathrm{X} 2=10.69$

$\mathrm{Df}=2$

Critical value at 0.05 level of significance $=5.99$. Since the $\mathrm{X} 2=10.69$ and the critical value at 0.05 level of significance is 5.99 , which is less than the observed $\mathrm{X} 2$, we reject $\mathrm{Ho}$ (null hypothesis) and accept $\mathrm{H} 1$ (alternative hypothesis). Our conclusion is that the cooperation between the ministry of labour and the department of correctional services will help to minimise unemployment and crime rates. The argument here is that those working in the ministry of labour will be able to give information on job opportunities to those who are unemployed and thus reducing their propensity to commit crime as a means of survival. In the same vein, those in the ministry of labour will also be able to give offices of the correctional services information on how to secure job opportunities for criminals when they are released from jail. This will help in preventing criminals from committing further crimes as a means of survival, thus reducing the rate of recidivists going back to prison. This integration and cooperation between the two social structuresthe ministry of labour and the department of correctional services is viewed from the sociological perspective as the functional aspect of the social structure that keeps the social system stable.

In this research, one of the survey questions was 'while in prison, are you engaged in any skills or educational programmes? It emerged from the interviews that inmates are engaged in a number of skills and educational programmes. To mention a few, these include the following:

- Brick making

- Welding

- Problem solving skills

- Business skills training

- Farming

- Plumbing

- Vocational training

- Plastering

- Building training

- Painters and decorators

On completion of their sentences, and having acquired some of the above mentioned skills, ex-offenders go back for reintegration into their communities. For example, for an extended period of time, some of these ex-offenders remain 
unemployed. As a result of lack of employment opportunities, the conclusion is obvious. As Merton (1968) argued, members of these groups, because of unemployment would be under severe pressure to reject the legitimate means which do not help them seek success by legal means. Consequently, since members of these groups have also been labelled as criminals, these unintended effects of law could force the individuals to engage in crime and as a result promote a situation of recidivism. However if there could be coordination, cooperation, integration and interrelatedness between the department of correctional services and the ministry of labour, we could have a situation whereby exoffenders with certain acquired skills, being attracted to the department of labour for job placement, and skills development. Consequently, a decrease in the rate of crime and unemployment would be inevitable. The global skills shortage is magnified in South Africa, where the continued exodus of skilled labour coupled with the legacy of education inequalities has had a negative impact in many facets of the South African business.

Table 14: Minimum wage and Unemployment

\begin{tabular}{|l|c|c|c|}
\hline \multicolumn{1}{|c|}{ Responses } & $\begin{array}{c}\text { Yes, the minimum wage affects } \\
\text { the rate of unemployment }\end{array}$ & $\begin{array}{c}\text { No, the minimum wage does not affects } \\
\text { the rate of unemployment }\end{array}$ & Total \\
\hline Unemployed & 45 & 15 & 60 \\
\hline Convicts (prisoners) & 20 & 10 & 30 \\
\hline Experts on crime and labour matters & 15 & 5 & 20 \\
\hline \multicolumn{1}{|c|}{ Total } & 80 & 30 & 110 \\
\hline
\end{tabular}

The above table 14 shows that the majority of the respondents are of the view that the minimum wage legislation as entrenched in the basic conditions of employment act 75 of 1997, contributes to the high rate of unemployment. The point emphasised by the respondents is that many employers cannot afford to pay the minimum wage and because of this, they have to reduce the number of workers. A detailed oral interview we held with one of our respondents who is unemployed on the relationship between minimum wage legislation and the rate of unemployment had this to say: 'you see, since the minimum wage legislation came into existence, many employers I contacted for a job are not willing to absorb more labour because the minimum wage and other conditions of service which the employers complained bitterly that they cannot afford to pay new employees'. The minimum wage has left many of us unemployed and this has adversely affected our lives.

\section{Conclusion}

The findings of the study indicate clearly that unemployment contributes to the increase in the rate of crime in Kwa-Zulu Natal Province. The findings also reveal that the low level of education contributes to the high rate of crime and unemployment.

\section{Recommendations}

Although South Africa has a National Crime Prevention Strategy (NCPS) the starting point for any National Anti -Crime programme, is the acknowledgement that the police alone are unable to combat crime. This problem requires the coordinated efforts and assistance of diverse organizations and institutions such as prisons, business, trade unions, schools, welfare agencies, and religious institutions to prevent crime. Educational programmes aimed at reducing vulnerability to crime are essential in South Africa. A computerized database of unemployed should be developed which could serve as a "talent bank" for labour offices and employment agencies. Finally, cooperation and integration between the ministry of labour and the department of Correctional Services in particular, will help minimize the rate of crime and unemployment. The argument here is that those working in the ministry of labour will be able to give information on job opportunities to those unemployed and thus reducing their propensity to commit crime as a means of survival.

\section{References}

Banerjee, A., Galiani, S., Levinsohn, J., McLaren, Z. and Woolard, I. 2006. Why Has Unemployment Risen in the New South Africa? IPC Working Paper Series Number 35. International Policy Center Gerald R. Ford School of Public Policy

University of Michigan, USA.

Dreze, J., and K. Reetika. 2000. "Crime, Gender, and Society in India: Insights from Homicide Data." Population and Development Review 26, 335-52. 
Fafchamps, M., and B. Minten. 2006. "Crime, Transitory Poverty, and Isolation:Evidence from Madagascar." Economic Development and Cultural Change 54,579-603.

Fajnzylber, P., D. Lederman, and N. Loayza. 2000. "Crime and Victimization: An Economic Perspective." Latin American and Caribbean Economic Association. Economia 1, 178-219.

Hirschi, 1. (1969). Causes of Delinquency. Los Angeles: University of California Press

Kelly, M. 2000. "Inequality and Crime." The Review of Economics and Statistics 82,530-39.

Kingdon, G. and John Knight. 2001. Unemployment in South Africa: the nature of the beast. WPS/2001-15, Centre for the Study of African Economies. Department of Economics University of Oxford.

Ludwig, J., G. Duncan, and P. Hirschfield. 2001. "Urban Poverty and Juvenile Crime:Evidence from a Randomized Housing Mobility Experiment." Quarterly Journal Of Economics 116, 655-79.

Merton, R.K. (1968). SOCial Theory and Social Structure. New York: Free Press.

Raphael, S., and R. Winter-Ember. 2001 "Identifying the Effect of Unemployment on Crime." Journal of Law and Economics 44, $259-83$.

Seekings, J. and N. Nattrass (2006): Class, Race, and Inequality in South Africa, University of KwaZulu-Natal Press.

StatsSA (1998) Unemployment and Employment in South Africa, Statistics South Africa, Pretoria.

Todaro, M. (1977) Economics for a Development World. Longman. 